\title{
Identification of Structural Proteins of Bombyx mori Parvo-Like Virus (China Zhenjiang Isolate)
}

\author{
Meng Lv Qin Yao Yong Wang Xiaoyong Liu \\ Keping Chen Junhong Zhang Xiaogang Li \\ Institute of Life Sciences, Jiangsu University, Zhenjiang, PR China
}

\section{Key Words}

Bombyx mori $\cdot$ Parvo-like virus $\cdot$ Viral structural protein

\begin{abstract}
Objective: Bombyx mori parvo-like virus is a type of virus containing two single-stranded linear DNA molecules (VD1, VD2). In the present work, the structural proteins of $B$. mori parvo-like virus (China Zhenjiang isolate) (BmDNV-Z) were identified. Methods: The virions were purified by cesium chloride density gradient centrifugation from the feces of $B$. mori larvae infected with BmDNV-Z and analyzed by SDSPAGE, Western blotting and MALDI-TOF/mass spectometry. Results: There were seven polypeptides of the virions, named P1 to P7, which reacted with the anti-virion serum. In addition, two polypeptides, $\mathrm{P} 5$ and $\mathrm{P} 6$, were recognized by the antibody against a viral protein encoded by VD1-ORF3. Conclusion: The results showed that the viral polypeptides were mainly composed of 7 proteins named P1 to P7. Western blotting with anti-virion serum indicated that structural proteins P5, P6 and P7 had molecular weights of around 50, 55 and $130 \mathrm{kDa}$, respectively. They were the major immunogens of the virion. Among them, P5 and P6 were coded by VD1-ORF3 and P7 was encoded by VD2-ORF1. Taken together, three viral structural proteins encoded by VD1-ORF3 and VD2-ORF1 were identified in BmDNV-Z for the first time.
\end{abstract}

\section{KARGER}

Fax +4161306 1234 E-Mail karger@karger.ch www.karger.com

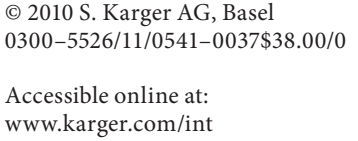

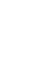




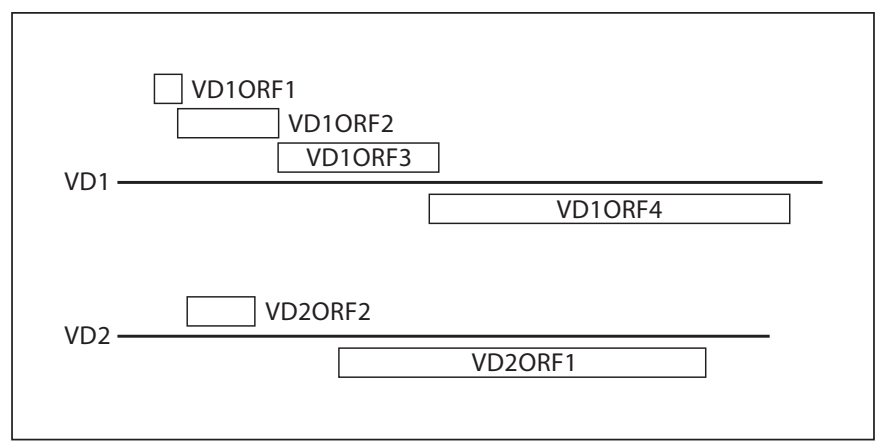

Fig. 1. The genome organization of BmDNV-Z. Horizontal bar represents the genomic DNA molecules. Boxes above the horizontal bars represent the ORFs found in the genome sequence and those below the horizontal bars represent ORFs found in the complementary strand.

cluded from the family Parvoviridae, because its genome includes two single-strand linear molecules and encodes its own DNA polymerase, characteristics which are not possessed by typical parvoviruses [2]. In 2001, Li and coworkers found that some amino acids in the conserved domain of viral protein (VP) 1 unique part (VP1up) matched the critical amino acids in the catalytic site of secretory phospholipase A2 (sPLA2) [3], and that PLA2s form a superfamily of key enzymes involved in physiological and pathological processes, such as lipid membrane metabolism, signal transduction pathways, inflammation and acute hypersensitivity, and degenerative findings could provide a basis to study the proposed diseases [4-6]. However, the conserved domain of PLA2 was absent in the VPlup of BmDNV-Z [Yao et al., in preparation]. This demonstrated that BmDNV-Z is different from the classic DNV with respect to physiological and pathological processes.

Generally, a parvovirus has 2-4 capsid proteins coded by one ORF with molecular weights ranging from 40 to $80 \mathrm{kDa}$. Reports on structural proteins of BmDNV-2 are inconsistent. In 1984, Kurihara et al. [7] purified BmDNV-2 from the infected midgut of $B$. mori larvae by ultracentrifugation in sucrose buffer solution and separated the proteins with SDS-PAGE. They found that there were 4 proteins with molecular weights of 51, 53, 116 and $121 \mathrm{kDa}$. In 1995, Sotoshiro and Kobayashi [8] purified BmDNV-2 from the infected larval bodies by cesium chloride gradient centrifugation and found that there were 6 polypeptides with molecular weights of $46.5,49$, $51,53,118$ and $120 \mathrm{kDa}$. However, the polypeptides of 118 and $120 \mathrm{kDa}$ could not be detected by the anti-BmDNV-2 antiserum.
In the present study, BmDNV-Z virions were purified from the feces of infected B. mori larvae by cesium chloride density gradient centrifugation and examined under electron microscope. Proteins of the virions were separated by SDS-PAGE and identified by mass spectrometry. The isolated proteins were verified by Western blotting using polyclonal antibody against virion and recombinant VP expressed in Escherichia coli.

\section{Materials and Methods}

Virus Propagation and Purification

The virus was purified as described previously [9] from the feces of BmDNV-Z-infected 4th instar larvae of B. mori strain Huaba. The virus was finally purified by cesium chloride density gradient centrifugation.

\section{Electron Microscopy}

The purified viral particles were treated with a negative contrast staining method. The samples were dropped on a copper screen with supportive film and were stained immediately for 23 min with $3 \%$ phosphotungstic acid after it dried up. The stained virions were observed under a transmission electron microscope (Tecnai-12, Phillips).

\section{SDS-PAGE}

$20 \mu \mathrm{l}$ of the purified virion sample was mixed with $4 \mu \mathrm{l}$ of $5 \times$ SDS-PAGE loading buffer solution containing $250 \mathrm{mM}$ Tris- $\mathrm{HCl}$ (pH 6.8), 10\% SDS, $0.5 \%$ bromphenol blue, $50 \%$ glycerin and $5 \%$ $\beta$-mercaptoethanol, and boiled for $10 \mathrm{~min}$. Electrophoresis was performed at $60 \mathrm{~V}$ for $30 \mathrm{~min}$ and then at $100 \mathrm{~V}$ for $90 \mathrm{~min}$ at room temperature. The protein molecular weight standard was from TaKaRa (Dalian, China). The gel was stained with $0.25 \%$ Coomassie blue R-250 for $3 \mathrm{~h}$ and then destained for $6 \mathrm{~h}$ using a mixture of $10 \%$ acetic acid and $5 \%$ ethanol.

\section{In-Gel Digestion}

Gel slices were collected manually using a pipette with a trimmed polypropylene tip. The proteins were digested with trypsin using modified procedures [10]. Briefly, the proteins in gel slices were destained by incubating the gels in ultra-pure water, $50 \mathrm{~mm}$ ammonium bicarbonate, $50 \%$ acetonitrile and $100 \%$ acetonitrile on a shaker and reduced with dithiothreitol and alkylated with iodoacetamide, and then treated with freshly prepared $20 \mu \mathrm{g} / \mathrm{ml}$ trypsin (Promega) solution containing $40 \mathrm{mM}$ ammonium bicarbonate and $10 \%$ acetonitrile at $37^{\circ}$ overnight. The gels were extracted with $5 \%$ formic acid in 1:1 water/acetonitrile. All solvents and reagents were purchased from Sigma.

\section{MALDI-TOF Mass Spectrometry Identification}

$1 \mu \mathrm{l}$ of each trypsin-digested peptide was mixed with $1 \mu \mathrm{l}$ of $10 \mathrm{mg} / \mathrm{ml} \alpha$-cyano-4-hydroxycinnamic acid (Sigma) saturated with $50 \%$ acetonitrile containing $0.1 \%$ trifluoroacetic acid, and applied onto a microtiter plate anchor chip (Bruker). A matrixassisted laser desorption ionization-time-of-flight (MALDITOF) mass spectrometer was used to identify the trypsin-digest- 
ed peptides by using the standard peptides for calibration according to the manufacturer's instructions (Ultraflex TOF/TOF, Bruker).

\section{Protein Identification}

Mascot software (Matrix Science, Ltd.) was used to search the NCBI (National Center for Biotechnology Information, http:// www.ncbi.nlm.nih.gov) protein databases and a local self-defined database containing protein fragments encoded by VD1-ORF4 to identify the target proteins. The parameter setting was as follows: missed cleavages as 1, fixed modification as acetylation of carbamidomethyl (C), variable modification as oxidation of methionine $(\mathrm{M})$ or Gln $\rightarrow$ pyro-Glu (N-term $\mathrm{Q})$, and mass tolerance as $0.2 \mathrm{Da}$. Peptide was identified with a Mowse score $>79(\mathrm{p}<0.05)$.

Prokaryotic Expression of VP and Preparation of Antibody

The VP coding region was amplified from BmDNV-Z genomic DNA as template using the forward primer BmDNV-VP-F 5'-AAGGCCTAATATTATGGGTAGAGTACTTGGCT-3' and reverse primer BmDNV-VP-R 5'-ATAAGAATGCGGCCGCTTAT TTATTGAAAACCAACAAGC-3', with BamH I and XhoI restriction sites at their $5^{\prime}$-ends, respectively. The target fragment was cloned into the expression vector pMAL-c2x (New England Biolabs, Inc.) to construct the recombinant expression plasmid pMAL-c2x-VP, which was then transformed into E. coli TB1 and was induced to express the VP by using $1.0 \mathrm{mM}$ isopropyl- $\beta-\mathrm{D}$ thiogalactopyranoside for $4 \mathrm{~h}$ at $37^{\circ}$. The recombinant protein was purified with the affinity column of a maltose-tagged purification system (New England Biolabs, Inc.), and the maltose-binding-protein-fused VP was used to immunize healthy rabbits and produce antibodies. The antibodies were purified with a protein A affinity column (Millipore)

\section{Western Blot Analysis}

Western blot analysis was performed according to the method of Towbin et al. [11] and Burnette [12]. The polypeptides resolved by SDS-PAGE were transferred to polyvinylidene fluoride membrane (Millipore). Viral structural polypeptides on the membrane were incubated with rabbit anti-BmDNV-Z virion serum and antibody against VP which was encoded by VD1-ORF3 and then incubated with the goat anti-rabbit IgG antibody conjugated with peroxidase to display color.

\section{Results}

Observation of Virions with the Electron Microscope

Electron micrograph of tungsten-stained virions showed that the viral solution contained a lot of small spherical particles (fig. 2). The viral particles were about $20 \mathrm{~nm}$ in diameter. No obvious large particles were seen, indicating that the prepared viruses were not contaminated with cell debris.

\section{Analysis of VP with SDS-PAGE and Western Blot}

SDS-PAGE analysis showed that the viral particles prepared from feces of the sick $B$. mori larvae infected

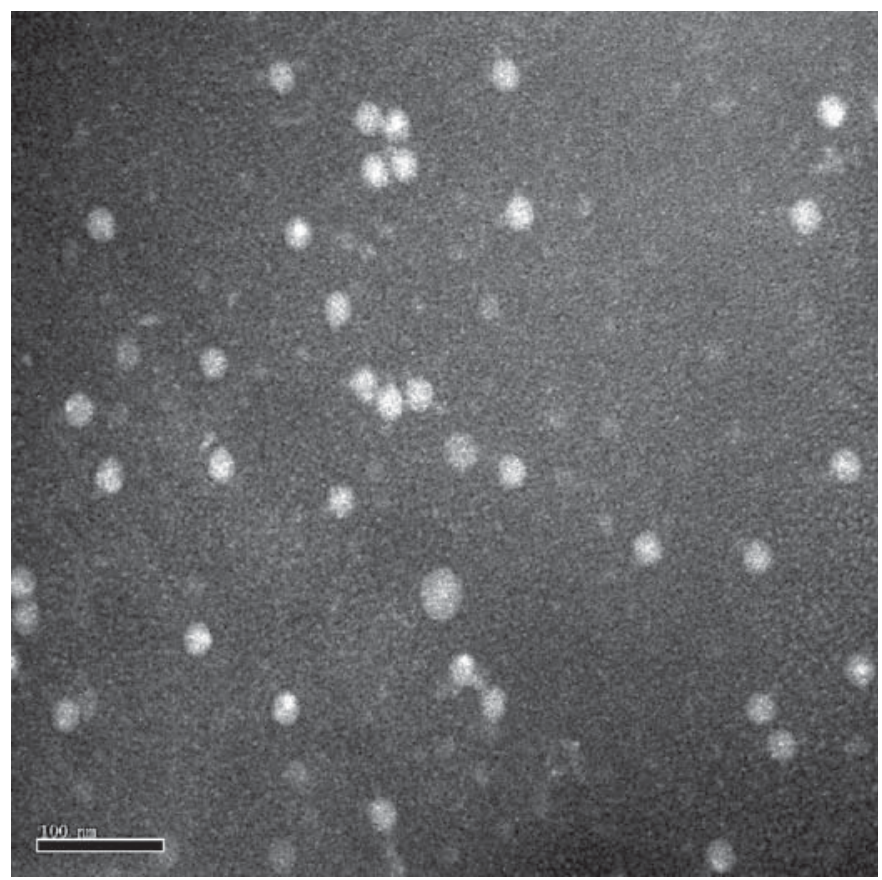

Fig. 2. Electron micrograph of silkworm parvo-like virus.

with BmDNV-Z had 7 proteins (fig. 3a, lane 2). The molecular weights of P1 to P4 were between 29.0 and 44.3 $\mathrm{kDa}$, those of $\mathrm{P} 5$ and P6 between 44.3 and $66.4 \mathrm{kDa}$, and that of P7 about $120 \mathrm{kDa}$. Western blot analyses using anti-BmDNV-Z serum showed that P1 to P7 could be recognized by anti-virion serum, suggesting that those polypeptides were major immunogens of the virion (fig. $3 b$ ). Western blot analysis with antibody against VP indicated that P5 and P6 were coded by ORF3 in VD1 (fig. 3c).

\section{Analysis of VP with MALDI-TOF/Mass Spectrometry}

VP bands P1 to P7 shown in SDS-PAGE (fig. 3a) were analyzed by MALDI-TOF/mass spectrometry. Highquality peptide mass fingerprints were obtained (fig. 4). After searching and comparing with the theoretical trypsin-digested peptides of existing proteins in databases, it was found that P5 and P6 were encoded by the VD1ORF3 of BmDNV-Z and P7 was encoded by the VD2ORF1 of BmDNV-Z. P4 had a limited sequence identity with a fragment of BmDNV-Z VD1-ORF4 (fig. 5). Molecular masses of peptides from trypsin-digested P3 showed no significant hits both in the NCB database and the local BmDNV-Z, VD1-ORF4 database. P1 and P2 were the triacylglycerol lipases of $B$. mori. The database search results are listed in table 1. 
Fig. 3. SDS-PAGE and Western blot analyses of proteins from BmDNV-Z virions. a Lane 1: protein molecular weight marker; lane 2: polypeptides from BmDNV$\mathrm{Z}$ virions named $\mathrm{P} 1$ to $\mathrm{P} 7$. b Western blot analysis with anti-BmDNV-Z serum. c Western blot analysis with anti-MBP-VP antibody.

Fig. 4. Peptide mass fingerprints of $\mathrm{P} 7, \mathrm{P} 5$ and $\mathrm{P} 4$.
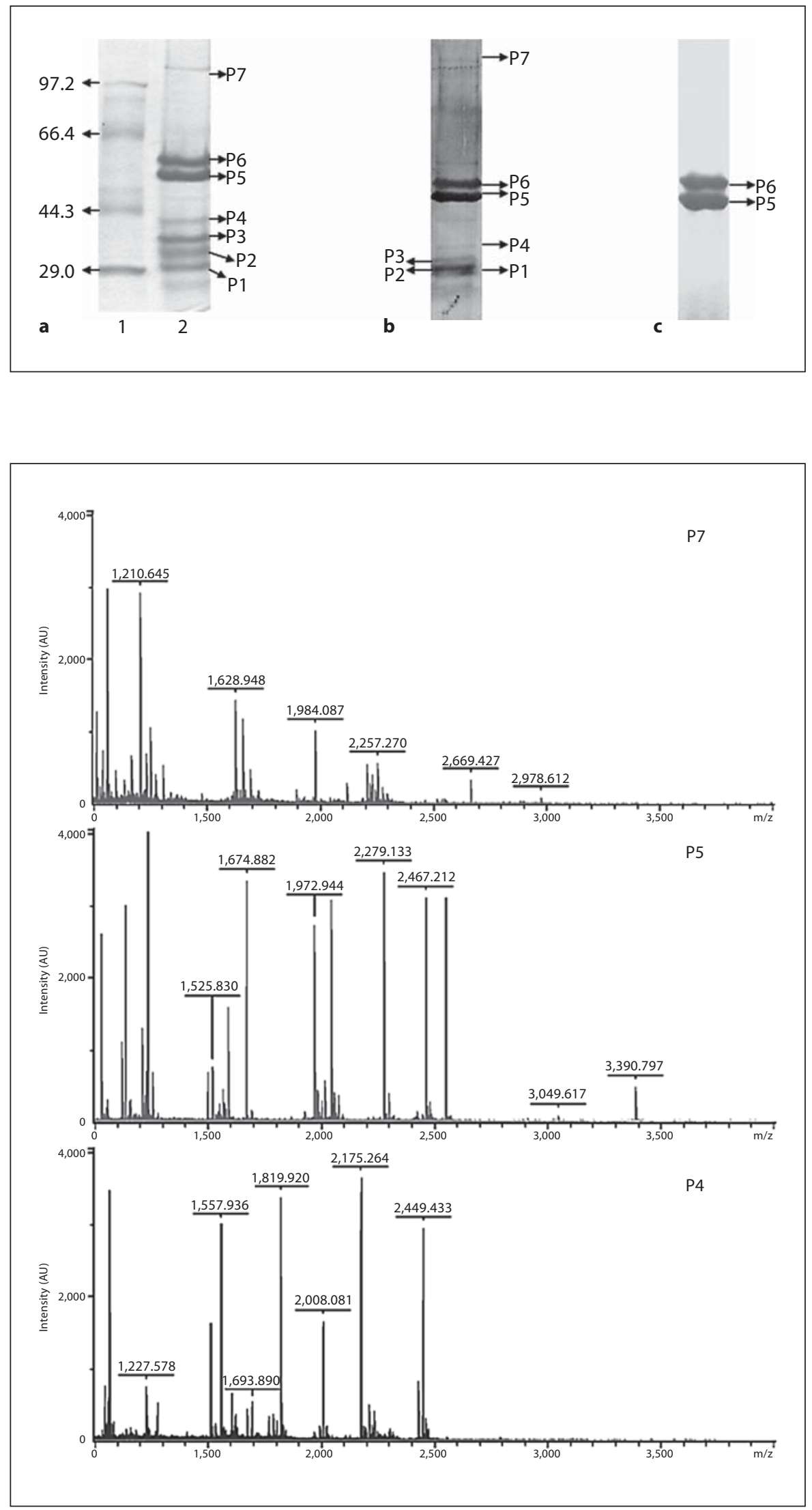
P4.

1 NNTFIVYFHN FKGYDHHIIL EOLLNKDSKH NTCRGKSINK IDVITHKDIL 51 SDFIRITFKD TFNFLPESLA SLANKLTTLK YTPDKFKEAF NSGKGEFPYE 101 WFDDFNKLEE IEVPQDPADW DSRLTNKKGT EEIIKKANQI WIDNOKQIFH 151 DYVLLYNELD YWLLLEVFEA FRDTTVNEDK IDPVYFDGAP GLTFYLARIYY 201 ENSLDIHVIP DKNVYLDVSR NIRGGVTQVV TKYANIEDVD ETIVYLDVNT 251 IYYSYCIIKQKL ANKYLGTLDA LPDNYDSDDN FCYFIKGDFS YPEYLHDLPA 301 HLSIPLIIPHQ YNNKLCTTFL DKKDHLIHSK VFKYYLSKGL VCDKIHYVYK 351 FKQEYIIKDY VETNIQKRNS STDPGTKDYY KLKNNNLFGK TCENVFKYKI 401 FSV,

P5.

1 IIGRVLGSLKR SFDSDVGGSG SGKRSNVSGG GDEGPIDASA ARAGGSGGGG 51 ASRGGASAEE KSDQPIYKPI EWKASFTIPF NYTTWEEIGT ELFCIPTQHS 101 LSAYFTRRLR FLEPYLSDVR FSFTDIETGP VRISNFIVLS DNLTTGNSIN 151 EVSSFVQNSK IVIIEEPEDSF TGMGYRLYEE SADGGLTPIG IPYENLCSRQ 201 NHGQLKQLVV LTRNAGADSI TESFENVVII PCQERDVGNS FTIDRSHTNR 251 LTAGSAEAVN ROTTTTGNTG YLYIKEVTGS GVOPIVDOLA ATNIIKDSINV 301 NRKWIREHSG LKIIDRDDVL SIGTPQYHSY LNSAASTNLA SAGKWLLKXPF 351 YRFDGTLIINP NTSTAPGVVI GRDARGEYFE ALIYAPHARY SEPEKRSDCG 401 QSRDWIQRAW SRAPSNKHTF LSIIPIRKSD GSLIKIRANC KVEQYINITT P6. 451 HYKSENIQGN VTQDINQGED VYRSPPIIRQI SARINPGGSP TGGLVVNK.

1 IGGVLGSLKR SFDSDVGGSG SGKRSNYSGG GDEGPMDASA ARAGGSGGGG 51 ASRGGASAEE KSDQPIYKPI EHKASFTIPF NYTTWEEIGT ELFCIPTQHS 101 LSAYFTNRLR FLEPYLSDVR FSFFDIETGP VRISNFIVLS DNLTTGNSIN 151 EVSSFVQNSK IVIFEPEDSF TGMGYRLYEE SADGGLTPIG IPYENLCSRQ 201 NHGQLKQLVP LTRNAGADSII TESFENVVII PCQEFDVGNS FTIDRSHINF 251 LTAGSAEAVN RQTTTTGNTG YLYIKEVTGS GVQPIVDQLA ATNIKDSNNV 301 NNKMIREHSG LKIIDRDDVL. SIGTPQYHSY LNSAASNNLA SAGKHLFKRPF 351 YRFDGTLINP NTSTAPGVVI GRDARGEYFE ALIYAPHARY SEPEKRSDCG 401 QSRDPIQRAM SRAPSNKHTF LSIIPIRKSD GSLIIKIRANC KVEQYINITF 451 HYKSENIQGN VTQDINQGED VYRSPPIIRQI SARINPGGSP TGGLLVFN.
P7.

1 IRLRRLYVC AVITAINSLS QSDLIQIFE. IETIIIRLSR TFNGDISTIN 51 NFYRILWSV ELFNDLLVEL DTPAVSMLL LFEDEDTVPN DCLGIVGQIL 101 IBYTDIPNDG SLTYLNIGTI SSLTVTLDN LYLILTVIYN NGRETIQEVH 151 NTGSPTIVD FYEIKHOTF QEIKTSIYYV NFINFVEYT VEIBDIIVT 201 RNIIRTNMMS TQQRSRSRIA FICQBAIDPD IREQLQESA ILAKLHDMD 251 TLEYYGISFL REYYIAYFQY TIYAETQRLD PERYDDPLEX NYIYINRIV 301 ALFRQVELAP RYAERAXPEG LLYPSLWDL FWARPPIRG SIPSGIGQLH 351 PISTTVCCIT RGPTSAVGSL KCYQVPLQTV YTYPQDLRTI DVGDITIRLE 401 PNQYIILRLR IISTGICNPQ TIVRRLNINY FCSSCSGPNL ICLEQNORYN 451 NRGSALNOYS FDUSNIEVP AYYVIEGISS AIYDLNPTCQ LIINTRLRQR 501 LFVLQTPSVA BYTIMGITRP VIKFINIOFN LGTIFLSYRD ICATFYTTR 551 LVIPRCDNAY DFNLPNIPG NSLATGTGVR VCNLPFRFG VQRCPEGPSA 601 LLPRYNFANI NIIDQLQELN IFNTSPQYI NRRYNNTER ILTNAPIAS? 651 NSAIDDLARL IIDEGIRLDA LEDRVERIED YIIESSXITI MDVLNIRTR 701 YDVRGIIRDS ARLIRTASIV ARKSLRGSFX RNWWFDIGN BIDSLTRVTR 751 NWQFNPVEI NTGSIYDTIH GRRKTSISNP TIRISNLDNI ITPRVLHDN 801 FRLPSTSLDV KDLINTNWI SITTQRSFID RLRDPKTGTN GDIUPYGWE 851 TLASPIEQLG PLGKFGYND ISPPSLSWFN TISESTYLFH TSVRTKSFEL 901 DINGWFYST RPSGIGEPSV LGATTIPERI KWGTLIEYD LKAGTGNTVS 951 LTRRNANVYY KNDVETYTEL DIDRLFEAFS SSKTYRERQN ESTDMKMLYI 1001 SFMEQRTRK RRVIQTQPIA NPLYLKFIDR LFDINTROGR LSGFKYNLN 1051 QNCQTFAKTQ SQLLTRGITN WQINDQGLLG FLENTKQIRR REPSLSSGIT 1101 ETSHGSTSPV VRALYSESN ICYYAKINUI SSIIRIXKNR YSILDRAYKN 1151 DNTIRTVICT .

Fig. 5. Matched peptides of P7, P6, P5 and P4 are shown in shaded areas.

Table 1. MALDI-TOF/mass spectrometry identification of proteins from BmDNV-Z virions

\begin{tabular}{|c|c|c|c|c|c|}
\hline No. & Score & NCBI accession number & $\begin{array}{l}\text { Mass } \\
\text { Da }\end{array}$ & Protein name & $\begin{array}{l}\text { Sequence } \\
\text { coverage, \% }\end{array}$ \\
\hline 1 & 90 & gi114050855 & 32,242 & triacylglycerol lipase of $B$. mori & 40 \\
\hline 2 & 112 & gi114050855 & 32,242 & triacylglycerol lipase of $B$. mori & 49 \\
\hline \multirow[t]{2}{*}{3} & 55 & gi38046528 & 24,339 & VP1 of foot-and-mouth disease virus-type Asia 1 & 32 \\
\hline & 10 & Q4U3C3_BMDNV & 42,799 & BmDNV-Z VD1-ORF4 (668-1,038aa)* & 7 \\
\hline \multirow[t]{2}{*}{4} & 80 & gi123217725 & 46,116 & Pol protein of human immunodeficiency virus 1 & 30 \\
\hline & 8 & Q4U3C3_BMDNV & 39,637 & BmDNV-Z VD1-ORF4 (463-865aa)* & 12 \\
\hline 5 & 179 & gi28932924 & 51,541 & structural protein of B. mori densovirus Zhenjiang & 58 \\
\hline 6 & 193 & gi28932924 & 55,185 & structural protein of $B$. mori densovirus Zhenjiang & 53 \\
\hline 7 & 128 & gi189007679 & 133,876 & structural protein of $B$. mori densovirus Zhenjiang & 22 \\
\hline
\end{tabular}

* The local BmDNV-Z, VD1-ORF4 database was used for comparison. This database contains only 4 polypeptide fragments in accordance with 4 functional domains of a protein encoded by VD1-ORF4. 


\section{Discussion}

The two single-stranded linear DNA molecules (VD1 and VD2) from BmDNV-Z are separately packed into a nonenveloped icosahedral capsid. The capsid proteins play important roles in protecting the genome and also in determining host specificity by interaction between structural proteins and host receptors [13]. In the present study, we found 7 polypeptides in viral particles from feces of the infected $B$. mori larvae. Of them, 3 structural proteins, P5, P6 and P7, constituted the structural proteins of BmDNV-Z viral particles, which was not fully consistent with previous studies.

Structural protein P7 is coded by VD2-ORF1. Hayakawa et al. [14] suggested that VD2-ORF1 coded the largest viral structural protein. They expressed the polypeptides encoded by C-terminal 600 nucleotides of VD2ORF1, and the product could be recognized by the antiserum against BmDNV-2 virions, which is consistent with our finding. In our study, we found that $\mathrm{P} 7$ was coded by the entire sequence of VD2-ORF1, as shown from the MALDI-TOF/mass spectrometry analysis, and demonstrated that VD2-ORF1 is the gene that encodes the largest structural protein of $\mathrm{BmDNV}-\mathrm{Z}$ for the first time.

Structural proteins $\mathrm{P} 5$ and $\mathrm{P} 6$ were encoded by VD1ORF3 of the viral genome. Our results from Western blot analysis showed that P1 to P7 could react with antibody against viral particles, suggesting that $\mathrm{P} 1$ to $\mathrm{P} 7$ were components of the viral particles. The result of P5 and P6 being able to react with the antibody against VP indicated that P5 and P6 were encoded by VD1-ORF3 and are the major structural proteins of BmDNV-Z. According to the matched peptides of P5 and P6 (fig. 5), we speculated that P6 and P5 were coded from the first and second methionine of VD1-ORF3, respectively. Indeed, the observation that several structural proteins translate from one ORF is very common in parvoviruses. For instance, VPs of densonucleosis viruses of Galleria mellonella, Junonia coenia and Mythimna loreyi are all translated from one ORF by a leaky scanning mechanism [15-17].

P4 might be encoded by VD1-ORF4 of BmDNV-Z which shows high sequence identity with VD1-ORF1 of BmDNV-2. In 2000, Hayakawa et al. [14] speculated that amino acids 329-1,115 of the structural protein encoded by VD1-ORF1 of BmDNV-2 contained conserved sequences among various DNA polymerases. They also expressed the 1,000 nucleotides of the N-terminus of VD1ORF1 and showed that the anti-BmDNV-2 serum recognized the N-terminus of VD1-ORF1. In our study, P4 could be recognized by the antiserum against $\mathrm{BmDNV}$ -
Z. Mascot searches of the protein database initially identified P4 as a HIV-1 DNA polymerase protein. This protein has a very high sequence identity with the DNA polymerase encoded by VD1-ORF4. A comparison with sequences in the self-defined database showed that the coverage between P4 and the VD1-ORF4 DNA polymerase segment (amino acids 463-865) reached $12 \%$. Therefore, we speculated that P4 might be the spliced product of the protein encoded by VD1-ORF4. However, P4 might not be the viral structural protein but another protein that had been packaged into the virus and had other roles. An examination of the polypeptide obtained by Hayakawa et al. [14] from the expression of the N-terminal 1,000 nucleotides of BmDNV-2 VD1-ORF1 indicated that the polypeptide's C-terminus is the basic region with an isoelectric point of around 8.16. We speculated that this basic region had a similar function as histone in eukaryotic chromosomal organization and therefore was the viral nucleoprotein. The composition of $\mathrm{BmDNV}$ particles is different from the parvovirus particles. The parvovirus particles contain polyamines such as spermine and spermidine. Therefore, further in-depth researches are required to confirm whether $\mathrm{P} 4$ protein is a viral nucleoprotein.

P1 and P2 were identified as the triacylglycerol lipase of B. mori. During primary infection, the virus must have the essential protein to start infection and cause host change for further infection. The host cell-derived protein components of viruses can subsequently serve diverse functions during the viral life cycle. The roles of these host-derived proteins have been receiving increasing attention, specifically in connection with HIV infection and the development of AIDS in humans [18]. P1 and P2 might be the proteins being packaged into the virus to play a role in primary infection. Further research into P1 and $\mathrm{P} 2$ is being undertaken in our laboratory to investigate the function of the triacylglycerol lipase in virus infection.

\section{Acknowledgements}

We thank Dr. Haifeng Shi for his support and assistance. The research is financed by the National Natural Science Foundation of China (30871826), the China National ' 863 ' Project (No. 2008AA10Z145), and a grant from the Jiangsu Sci-Tech Support Project-Agriculture (No. BE2008379). 


\section{References}

1 Bando H, Choi H, Ito Y, Nakagaki M, Kawase S: Structural analysis on the single-stranded genomic DNAs of the virus newly isolated from silkworm: the DNA molecules share a common terminal sequence. Arch Virol 1992;124:187-193.

-2 Ito K, Kidokoro K, Sezutsu H, Nohata J, Yamamoto K, Kobayashi I, Uchino K, Kalyebi A, Eguchi R, Hara W, Tamura T, Katsuma S, Shimada T, Mita K, Kadono-Okuda K: Deletion of a gene encoding an amino acid transporter in the midgut membrane causes resistance to a Bombyx parvo-like virus. Proc Natl Acad Sci USA 2008;105:7523-7527.

$\checkmark 3$ Kurihara Y, Watanabe H, Maeda S, Shimizu T: Chemical characteristics of a previously undescribed densonucleosis virus isolated from the silkworm, Bombyx mori. J Sericult Sci Jpn 1984;53:33-40.

$\checkmark 4$ Balsinde J, Balboa MA, Insel PA, Dennis EA: Regulation and inhibition of phospholipase A2. Annu Rev Pharmacol Toxicol 1999;39: 175-189.

5 Dennis EA: The growing phospholipase A2 superfamily of signal transduction enzymes. Trends Biochem Sci 1997;22:1-2.

-6 Kramer RM, Sharp JD: Structure, function and regulation of $\mathrm{Ca}^{2+}$-sensitive cytosolic phospholipase A2 (cPLA2). FEBS Lett 1997; 410:49-53.
7 Kurihara Y, Watanabe H, Maeda S, Shimizu T: Chemical characteristics of a previously undescribed densonucleosis virus isolated from the silkworm, Bombyx mori. J Sericult Sci Jpn 1984;53:33-40.

8 Sotoshiro H, Kobayashi M: Identification of viral structural polypeptides in the midgut and feces of the silkworm, Bombyx mori, infected with Bombyx densovirus type 2. J Invertebr Pathol 1995;66:60-67.

9 Wang YJ, Yao Q, Chen KP, Wang Y, Lu J, Han $\mathrm{X}$ : Characterization of the genome structure of Bombyx mori densovirus (China isolate). Virus Genes 2007;35:103-108.

10 Mirza UA, Liu YH, Tang JT, Porter F, Bondoc L: Extraction and characterization of adenovirus proteins from sodium dodecylsulfate polyacrylamide gel electrophoresis by matrix-assisted laser desorption/ionization mass spectrometry. J Am Soc Mass Spectrom 2000;11:356-361.

11 Towbin H, Staehelin T, Gordon J: Electrophoretic transfer of proteins from polyacrylamide gels to nitrocellulose sheets: procedure and some applications. Proc Natl Acad Sci 1979;76:4350-4354.

12 Buenette WN: 'Western blotting': electrophoretic transfer of proteins from sodium dodecyl sulfate polyacrylamide gels to unmodified nitrocellulose and radiographic detection with antibody and radioiodinated protein A. Anal Biochem 1981;112:195-203.

13 Gardiner EM, Tattersall P: Evidence that developmentally regulated control of gene expression by a parvoviral allotropic determinant is particle mediated. J Virol 1988;62 1713-1722.
14 Hayakawa T, Kojima K, Nonaka K, Nakagaki M, Sahara K, Asano S, Iizuka T, Bando H: Analysis of proteins encoded in the bipartite genome of a new type of parvo-like virus isolated from silkworm - structural protein with DNA polymerase motif. Virus Res 2000;66:101-108

15 Tijssen P, Li Y, El-Far M, Szelei J, Letarte M, Zadori Z: Organization and expression strategy of the ambisense genome of densonucleosis virus of Galleria mellonella. J Virol 2003; 77:10357-10365.

16 Bossin H, Fournier P, Royer C, Barry P, Cerutti P, Gimenez S, Couble P, Bergoin M: Junonia coenia densovirus-based vectors for stable transgene expression in sf9 cells: influence of the densovirus sequences on genomic integration. J Virol 2003;77:1106011071.

17 Fediere G, El-Far M, Li Y, Bergoin M, Tijssen P: Expression strategy of densonucleosis virus from Mythimna loreyi. Virology 2004; 320:181-189.

18 Liu XY, Chen KP, Cai KY, Yao Q: Determination of protein composition and host-derived proteins of Bombyx mori nucleopolyhedrovirus by 2 -dimensional electrophoresis and mass spectrometry. Intervirology 2008;51: 369-376. 